\title{
Legality of Testament Cancellation Law and Property Ownership According to Fiqh Al-Syafi'iyyah
}

\author{
Karimuddin ${ }^{1}$, Khairun Asyura ${ }^{1}$, Syamsul Bahri ${ }^{1}$, Syarkawi ${ }^{1}$, Nurul Husna ${ }^{2}$, Fathiatul \\ Ghina $^{2}$ \\ ${ }^{1}$ Lecturer in Islamic Institute of Al-Aziziyah Samalanga, Bireun Aceh, Indonesia \\ ${ }^{2}$ Student in Islamic Institute of Al-Aziziyah Samalanga, Bireun Aceh, Indonesia \\ Email: karimuddien@yahoo.com
}

\begin{abstract}
:
Any person who has sufficient assets may inherit a portion of the assets as long as it does not harm the heirs and people who are forced to intend or will not intentionally in their will, the will is invalid. The person who has the will must fulfill the requirements, including adults, sensible, independent and of his own will. So it is not a will made by a minor child and a crazy person. In other cases when the testament inherits the estate and then he cancels the will, or the will inherits more than a third of the total assets but the heir cancels the will, then there will be a problem regarding the legality of the will and the status of ownership of the estate after the cancellation of the will. Based on these problems, a study is made to find a legal clarity that could be a reference for every policy maker. The results of the study and research can be concluded, al-Syafi'iyyah states that a will is only valid within a third of the inheritance as long as there is no permission from the heirs to testate to more than one third of the assets. exceeds the said level. A will also becomes nullified if a person who has a will cancels his will or inherited property no longer belongs to someone who has a will. Ownership of a will after the will is canceled depends on the reason and the person who cancels it. If the cancellation is carried out by the willor then the property is returned to the will of the testator, but if the cancellation of the will is due to a will that exceeds one third of the assets then the will is the right of the heir.
\end{abstract}

Keywords :

legal legality; revocation of the will; property ownership; al-shafi' iyyah figh

\section{Introductioin}

The will is part of the inheritance law. The definition of a will is a statement of one's will about what will be done to his property after death. In the implementation there are several conditions that must be met in order to be implemented well. The above is a notion of testament relating to inheritance in inheritance law. A will can also be interpreted as advice or words conveyed or desired by a person to be carried out after he dies. ${ }^{1}$

Such a will is related to the right of authority (responsibility) that will be carried out after he dies, for example someone wills to someone else to help educate his child later, repay his debt or return the goods he once borrowed.

Basically a will is a moral obligation for someone to fulfill the rights of others or their relatives, because that person has contributed a lot or helped his business life, while the person is not included in the family that gets the inheritance. This means that the will is a revision of the

${ }^{1}$ A. Rahman I Doi, Hudud dan Kewarisan (Jakarta: Raja Grafindo Persada, 1996), p. 195 
inherited law that has been prescribed. But even so there are certainly cases that can make a will be nullified and the limit of assets that can be inherited.

Moving on from the problems mentioned above, on this occasion the author will try to explain perfectly the legality of the cancellation of a will and the right of ownership of the will in a fiqh manner.

\section{Literature Review}

\subsection{Understanding the Will}

The person who has the will is the person who delivered the message when he lived to be carried out after being observed. According to syara 'a will is a gift from someone to another person in the form of goods, receivables or benefits to be owned by a person who is given a will after the person who has the will dies. ${ }^{2}$ Some fuqaha interpreted that the will is a voluntary giving up of ownership which is carried out after the giver dies. From this it is clear the difference between a grant and a will. Ownership obtained from the grant took place at the same time; whereas the possession obtained from the will takes place after the person who has the will dies. This is in one way; while from another aspect the grant is in the form of goods, while the will can be in the form of goods, receivables. ${ }^{3}$

A will will allow someone who has more assets to set aside part of the asset and not put in the amount of inheritance that will be distributed to the heirs. So after considering the needs of the heirs, some of the assets will be given to other parties who are still in need, such as poor relatives while he is not classified as an heir who gets an inheritance. It is a moral obligation for someone to fulfill the rights of others or their relatives, because that person has contributed a lot to him or helped with his business and life, while he is not one of the families who get part of the inheritance. The will serves as a virtuous deed that can cleanse itself from the burden of sin, besides aiming to help his brothers in need, or for the public benefit which is blessed by Allah SW'T.

\subsection{Legal Basis of Wills}

The position of the will in inheritance law is very important. This is stated by the many verses of the Qur'an and the Hadith of the Prophet Muhammad. Which explains the will and becomes the basis of the will, including:

Meaning: It is obliged upon you, if one of you arrives (signs) of death, if he leaves a lot of wealth, Wills for his parents and relatives intimately (this is) an obligation on those who fear. (Q. S. Al-Baqarah [2]: 180). ${ }^{4}$

Based on the verse above shows that if someone is in a state of maradh al-mawt and has excess assets, it is recommended to be intending to relatives who are in need. On the other hand those who listen or receive a will, are required to be honest and fair. Because if these people intentionally change the contents of the will, this will prevent the achievement of good intentions from the testament and will bear the sin for their actions.

Meaning: O you who believe, if one of you faces death, while He will testify, then let (the will) be witnessed by two people who are just among you, or two people of different faiths with you, if you are on your way on earth then you are overwritten by the danger of death. you hold the two witnesses after prayer (to

\footnotetext{
${ }^{2}$ Ibrahim Bajuri, Al-Bajuri, Syarhi 'Ala Fathul Qarib, Vol. II, (Semarang: Toha Putra, 1999), p. 26.

${ }^{3}$ Ibrahim Bajuri, Al-Bajuri, Syarhi 'Ala Fathul Qarib..., p. 30

${ }^{4}$ Departemen Agama, Al-Quran dan Terjemahnya.
} 
swear), then they both swear by the name of Allah, if you doubt: "(By Allah) We will not buy with this oath a small price (for someone's sake), even though $\mathrm{He}$ is close relatives, and not (also) We Hide the testimony of Allah; Surely we if then surely included those who sinned "(QS Al-Maidah [5]: 106). ${ }^{5}$

In essence a will is a kind of contract. Therefore, it is better for the will to be witnessed by two witnesses who are fair and Muslim. However, if the situation is forced or in a long journey that does not allow the existence of witnesses who are Muslim, then it is possible to take witnesses of different religions. The purpose of the witnesses mentioned in the paragraph above is expected in the case of wills to be easily resolved if there is a dispute in the future after the person who has the will died. ${ }^{6}$

a. Hadith Prophet SAW

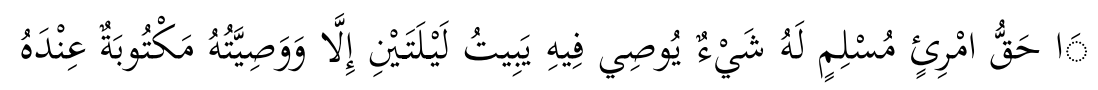

Meaning: No person will grant a Muslim a right, and his will will not be fulfilled for two nights unless his will is required by his side. (H. R. Bukharidan Muslim). ${ }^{7}$

The hadith gives guidance when a person has decided to make a will, so it is better to notify them in writing. The pre-Shaykh said that there is no better bond for a Muslim than his will is written when he has something to observe. This is due to concern for the testator who will have other desires that may interfere with his will and the omission of writing or announcing his will will be adversely affected after the deceased person dies.

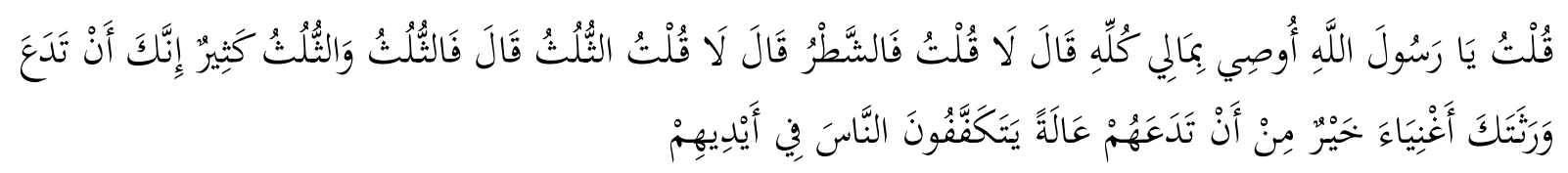

Meaning: From Sa'ad ibn Abi Waqash He said: I said: O Messenger of Allah, I am a rich man (rich) and no one can inherit me except a daughter. Do I give away two-thirds of my property? He replied: No. I ask again: Am I giving half? He replied: No. I ask again: Am I giving a third? He said: A third. A third is a lot. Surely you leave your heirs in a better state than you leave them in a poor state that will beg others. (H. R. Bukhari And Muslim). ${ }^{8}$

Based on the above hadith, it is a requirement for each person who wishes to put the interests of their heirs first. Because leaving the heirs in sufficient condition is better than leaving them in poor condition. ${ }^{9}$ The hadith also means that the will must not exceed one third of the total estate of the deceased person. Even less than a third is better

\footnotetext{
${ }^{5}$ Saefudin Zuhri, Keputusan Hukum Rasulullah, (Jakarta: Pustaka Azzam, 2000), p. 181

${ }^{6}$ Saefudin Zuhri, Keputusan Hukum Rasulullah ..., p.183.

${ }^{7}$ Muhammad bin Syihabuddin ar-Ramli, Nihayatul Muhtaj ila Syarhil Minhaj, Vol. 2, (Beirut:Dār Al-Fikr, 2000), p.41.

${ }^{8}$ Muhammad bin Syihabuddin ar-Ramli, Nihayatul Muhtaj ila Syarhil Minhaj..., p. 41.

${ }^{9}$ Ibrahim Bajuri, Al-Bajuri, Syarhi 'Ala Fathul Qarib..., p. 28.
} 


\section{Discussion}

\subsection{Provisions of Property That Can Be Announced According to Fiqh Syāfi'iyyah}

For the sake of leftist interests, someone is entitled pass on a small portion of his property. It is meant to be a will harm the heirs left behind. In accordance with the order of the Messenger of Allah. Al-Bukharidan Muslim narrated:

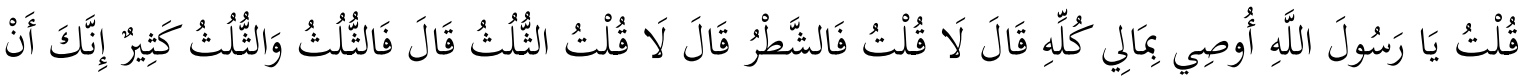

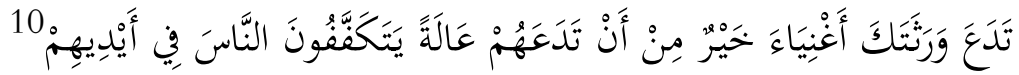

Meaning: From Sa'adibn Abi Waqash He said: I said: YaRasulullah, I am a rich man and no one can inherit me except a daughter. Do I give away two-thirds of my property? He replied: No. I ask again: Am I giving half? He replied: No. I ask again: Am I giving a third? He said: A third. A third is a lot. Surely you leave your heirs in a better state than you leave them in a poor state that will beg others. (H. R. Bukhari And Muslim).

The hadith explicitly prohibits the will of more than a third of the property. The will only applies to a third of the inheritance. So more than a third of wills are considered good. Thus explaining that it is important to consider the heirs' needs before someone decides to leave. ${ }^{11}$

There is a prohibition against the will of more than one-third of the assets as presented above, aimed at preventing the will of the deceased to harm the heirs. For each person who will pass on some of his property, it is best to put his heirs first. Because leaving the heirs in sufficient condition is better than leaving them in poor condition. So it is necessary to establish a will restriction of only one third of the estate. As the Imam Nawawi put it:

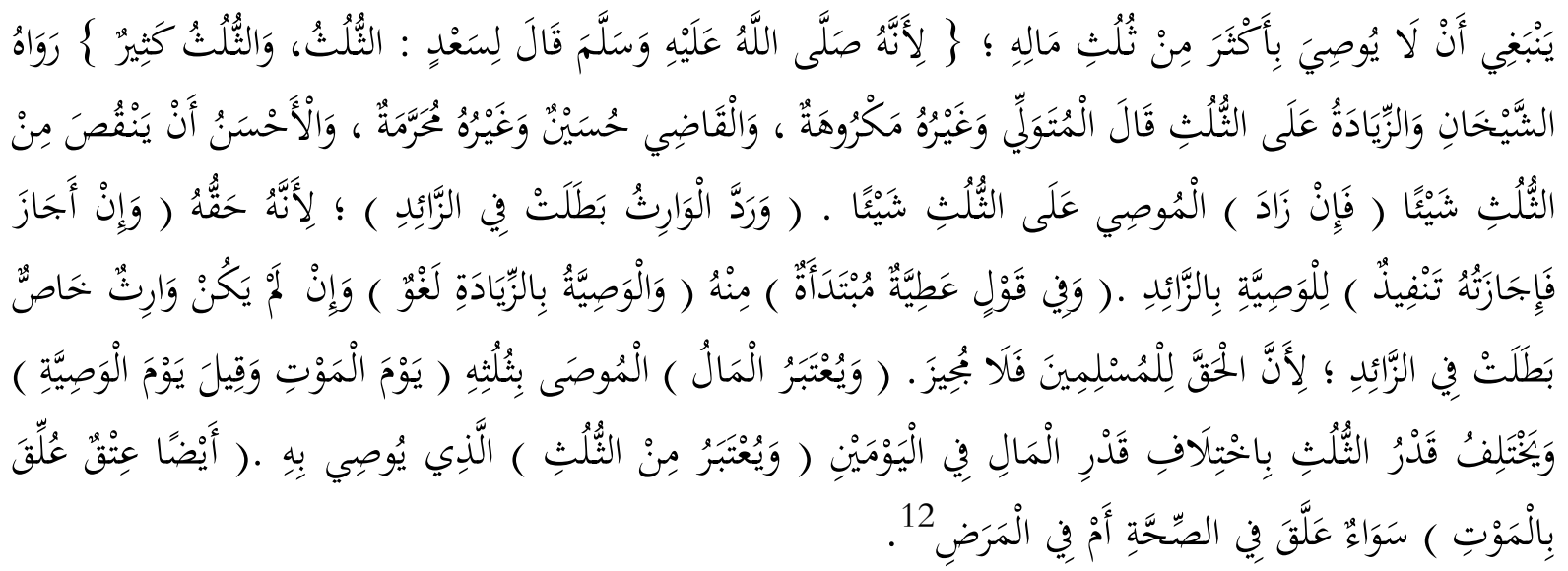

Meaning: A person who is free will not be able to pass on his / her personal income, hence the Muslim Brotherhood. According to the opinionSubscribe to the bank and the website. However, according to Qadhi Husain it is illegal to give away a third of the property while the beneficiary does not approve it, so the beneficiary of more than a third of it is void, because the beneficiary is the rightful heir. And if the heirs allow more than one third of the estate then the will is valid. It is then argued that the will of more than one third of the property is not a will but

\footnotetext{
${ }^{10}$ Imam Bukhari, Shahih al Bukhari, Juz 3, (Beirut: Dar Al- Kutub Al-Ilmiyah, t.th), p. 315

${ }^{11}$ Sayyid Bakri, l'anatu At-Thālibin, Vol. 3, (Semarang: Toha Putra, t.t), p. 208.

${ }^{12}$ Al-Nawawi, Muhyi Al-Din, Yahya Ibnu Syrf, Minhajul Al-Thalibin, Jld: III, (Beirut: Dār Al-Fikr, 2006), h. 162
} 
a mere gift or grant. A will that exceeds one third of the estate does not include the will, and if the heir does not agree, the will is void. These differences will affect the size of the property that will become the will. Including one third of the will is the slave who is freed at death when the will of the will is the will when healthy or sick.

According to Imam Nawawi, the will is more than one third of the law and this is a strong and illegal opinion when a person intends to prevent the property from being inherited. Concerning the limits of property that can be ascertained from the above opinion that the beneficiary does not inherit more than one-third of his property, and preferably less than one-third of the estate, for the benefit of the heirs he has left, let alone the heirs of the deceased beneficiaries and their lives. always in want.

\subsection{Revocation of the Will According to the Fiqh Syāfi'iyyah}

In the formulation of the Shayfi'iyyah jurisprudence it is stated that the will may be revoked if the testator does not qualify for the will or the person receiving the will is not entitled to the will, the will also may be revoked if the person receiving the will first dies. from the person giving the will and the will can also be canceled if the will was destroyed before the person received the will. ${ }^{13}$ In more detail the will becomes void according to FiqhSyafi'iyah as Sayyid Bakri states in his Book:

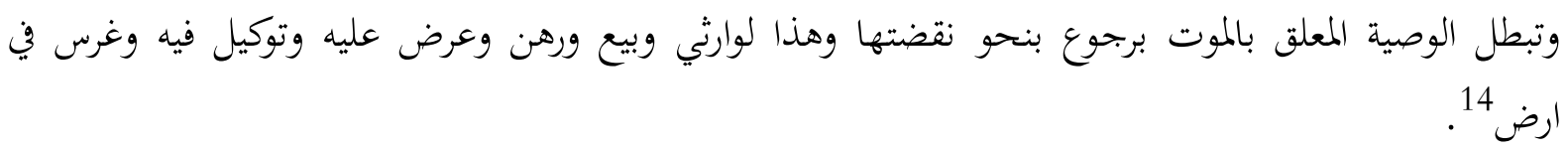

Meaning: The will becomes void with a few things between the ain:

a. The testator took back the will, just as I canceled the will for you.

b. Goods that were passed out of the executor's estate before the death (not the title of the executor), though eventually returned to the executor's possession, as the will say, belong to my heirs.

c. The executor sells goods that have been stored or used as mortgages or damaged goods (lost, burned or destroyed by flood) before the deceased dies.

d. The executor plans to sell the property or plans to make the mortgage.

e. Planting trees on property maintained by the testator.

The will also invalidates more than a third of the property without the consent of the heirs and the executors do not fulfill the will for example, unmarried children, forced people, crazy people, people who are prohibited from using their property due to excessive debt or waste according to one opinion and I am even a slave. While drunk people are legal to give a will because drunk people are like mukallaf. ${ }^{15}$

According to the author's analysis the cancellation is based on what has been mentioned except on the property (earth) that the plant has grown, because the tree that was planted on the cultivated property has no effect on the will, and the will is still the will.

\subsection{The Law of Revocation of the Will according to FiqhSyāfi'iyyah}

The will is not a requirement for a person to perform a will or receive a will. Therefore, the testator can take back the stated will, whether it be a matter of property, benefit or matter of

\footnotetext{
${ }^{13}$ SayyidBakri, I'anatu At-Thālibin..., p. 215

${ }^{14}$ SayyidBakri, I'anatu At-Thālibin..., p. 215

${ }^{15}$ SayyidBakri, I'anatu At-Thālibin..., p. 200
} 
power. or region. The revocation of the will can be done either verbally or in deed, such as one giving the land to another person, then the person giving it to another person without notifying the person who has received the will. ${ }^{16}$

All Shafi'iyyah scholars agree that a will is not a necessity on the part of the will or the recipient of the will. Therefore, the willor may withdraw the will, whether the will is related to goods, benefits or power (territory). A will can be canceled at any time, whether when a will is in good health or sick. ${ }^{17}$

Imam Nawawi said:

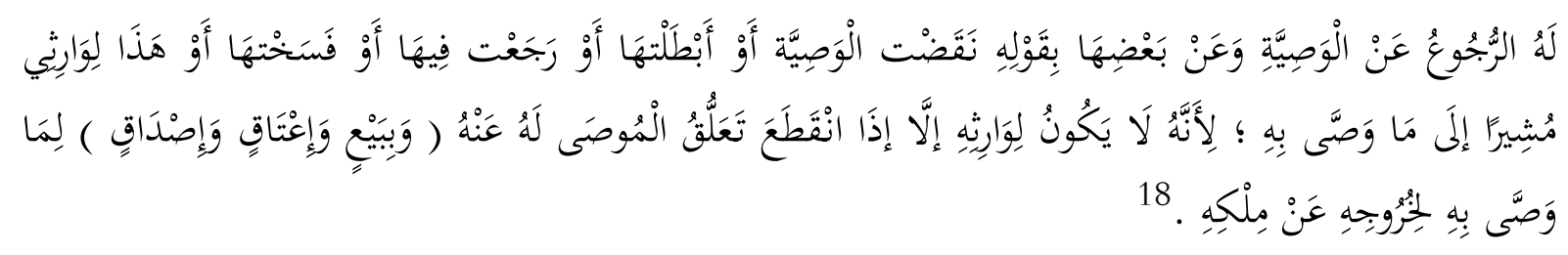

Meaning: It is permissible for a will to cancel and take back all his or her inherited assets or any part of it, on the grounds that the will belongs to his heir, or for the reason of selling the inherited item or checking the inherited servant and so on. The ability to take back the will because the treasure does not belong anymore.

According to the author's analysis, a person who has a will can cancel a will even without any reason because the inherited property is still fully his right, and the person who receives the will does not have the slightest right to the inherited property.

\section{Conclusion}

According to fiqh al-Syafi'iyyahwasiat only applies within the limit of one third of the inheritance as long as there is no permission from the heirs to bequeath more than one third of the assets, if the heirs give permission to intend more than one third of the property then it is possible to inherit more than that level. Shafi'iyyah's fiqh is stated that a will can be nullified if the person giving the will does not fulfill the conditions in the will or the person receiving the will is not entitled to the inherited item. A will also becomes invalid if a person who has a will cancels his will and the inheritance is no longer the property of a person who has a will, and a will becomes invalid if the inherited property is more than one third of the wealth. According to the Fiqh Shafi'iyyah the will is not a necessity / obligation that must be carried out by a person to give a will or receive a will. Therefore, the person giving the will may cancel the will that has been given to the will. Ownership of a will after the will is canceled depends on the reason and the person who canceled it. If the cancellation is carried out by the willor then the property is returned to the will of the testator, but if the cancellation of the will is due to a will that exceeds one third of the assets then the will is the right of the heir.

\section{References}

A. Rahman I Doi, Hudud dan Kewarisan (Jakarta: Raja Grafindo Persada, 1996).

Abdurrahman Al-Jaziri, Al-Fiqbu Ala Mazabibi Arba'ah, Terjemahan oleh H. Moh. Zukri, Jilid 4, (Semarang: Asy Syifa, 1994).

\footnotetext{
${ }^{16}$ Abdurrahman Al-Jaziri, Al-FiqhuAlaMazahibiArba'ah, Translated by H. Moh.Zukri, Vol. 4, (Semarang : AsySyifa, 1994),p. 327.

${ }^{17}$ SayyidBakri, I'anatu At-Thālibin...,p. 218

${ }^{18} \mathrm{Al}-$ Nawawi, Muhyi Al-Din, YahyalbnuSyrf, Minhajul Al-Thalibin..., h. 177
} 
Al-Nawawi, Muhyi Al-Din, Yahya Ibnu Syrf, Minhajul Al-Thalibin, Jld: III, (Beirut: Dār Al-Fikr, 2006).

Al-Imam Asy-Syafi'iy, Al-Umm, diterjemahkan Ismail Yakub, al-Umm (Kitab Induk) (Jakarta: Faizan, 1992).

Departemen Agama, Al-Quran dan Terjemahnya.

Ibrahim Bajuri, Al-Bajuri, Syarbi 'Ala Fathul Qarib, Jld: II, (Semarang: Toha Putra, 1999).

Imam Bukhari, Shahih al Bukhari, Juz 3, (Beirut: Dar Al- Kutub Al-Ilmiyah, t.t).

Muhammad bin Syihabuddin ar-Ramli, Nihayatul Mubtaj ila Syarbil Minhaj, Vol. 2, (Beirut:Dār AlFikr, 2000).

Saefudin Zuhri, Keputusan Hukum Rasulullah, (Jakarta: Pustaka Azzam, 2000).

Sayyid Bakri, I'anatu At-Thälibin, Vol. 3, (Semarang: Toha Putra, t.t). 